\title{
Cristãos-novos, Jesuítas e Inquisição: uma relação controversa em Portugal (séculos XVI e XVII)
}

\author{
Christians-New, Jesuits and Inquisition: \\ A relationship controversial in Portugal (sixteenth and seventeenth centuries)
}

\author{
JOSÉ EDUARDO FRANCO \\ Centro de Literaturas e Culturas Lusófonas e Europeias da Faculdade de Letras da Universidade de Lisboa - CLEPUL \\ CÉlia TAVARES \\ Universidade Estadual do Rio de Janeiro - UERJ
}

Resumo: Este artigo procura analisar aspectos das relações complexas entre os Jesuítas, Tribunal da Inquisição e Cristãos-Novos. A colaboração de jesuítas com as estruturas do Santo Ofício não obstou a que surgissem dentro da Companhia de Jesus vozes fortemente críticas e discordantes do modo de atuar daquele Tribunal que foi observado com prudência por parte das primeiras lideranças jesuítas. Por seu lado, os Cristãos-Novos tiveram desde o início grande acolhimento no seio da Ordem de Santo Inácio, destacando-se alguns descendentes de judeus à frente de posições de governo na Companhia de Jesus, a começar pelo segundo Superior Geral. Ao longo da história difícil de intolerância e perseguição inquisitorial em relação aos cristãos-novos estes encontraram destacados defensores da sua causa na Companhia de Jesus. Estas relações dilemáticas fazem desta relação triangular um tema historiográfico importante para compreender os tramas e dramas da sociedade o Antigo Regime.

Palavras-chave: Judaísmo; Inquisição; Cristãos-Novos; Jesuítas; Portugal; Antigo Regime.

\begin{abstract}
This paper analyses aspects of the complex relationship between the Jesuits, the Inquisition Court and the New Christians. The collaboration of Jesuits with the Holy Office institutions did not prevent that within the Society of Jesus there were strong critical and discordant voices being raised against this Court's practices, which were observed with caution by the first Jesuit leaders. For their part, the New Christians enjoyed a great reception within the Order of St. Ignatius from the beginning, with some Jewish descendants standing out in high positions in the Society of Jesus, such as the second Superior General. Throughout the difficult history of intolerance and inquisitorial persecution against the New Christians, the Jesuits were prominent advocates of their cause. These problematic relationships make this triangular relationship an essential historiographical subject in order to understand the plots and dramas of the Old Regime society.
\end{abstract}

Keywords: Judaism; Inquisition; New Christians; Jesuits; Portugal; Old Regime.

\section{Considerações preliminares}

Na reequação do quadro das relações dilemáticas entre duas instituições de natureza diversa existentes no seio da Igreja Católica cumpre começar por lembrar o facto de a Companhia de Jesus ter nascido em luta com os tribunais do Santo Ofício. O próprio percurso espiritual e universitário do seu fundador foi marcado por várias intimações, prisões e repreensões feitas pelos tribunais da Inquisição das cidades por onde Inácio de Loyola e os seus companheiros, oriundos quer de
Espanha, de França ou de Itália ${ }^{1}$, passaram, residiram e estudaram.

Inácio, os seus Exercícios Espirituais e o seu grupo de seguidores não deixaram de ser fortemente estigmatizados pela suspeita de estarem enfermados de erasmismo, de alumbrismo e de outros "ismos" que faziam tremer os guardiões da ortodoxia daquele tempo, numa época em que a Inquisição estava a reforçar a sua vigilância e

\footnotetext{
1 Ludwig Marcuse, Soldier of the Church: A life of Ignatius Loyola (Londres: Ulan Press, 2012), 287.
} 
a criar um clima de suspeição generalizada ${ }^{2}$. Quando, ainda em Espanha, Inácio de Loyola começou a difundir os Exercícios Espirituais entre os seus colegas e outras pessoas, foi preso pela Inquisição por um breve período. Foi-lhe inclusive decretada a sentença que o impedia de pregar antes da conclusão de seus estudos, apesar de os Exercícios Espirituais serem reconhecidos como doutrina ortodoxa e moral irrepreensível, o que indica a tensão entre o futuro fundador da ordem jesuítica e o Santo Ofício.

Mas, no quadro da mentalidade do tempo e dos jogos de poder e de influência a que a Companhia de Jesus não poderia ser alheia, sob pena de hipotecar a sua implantação e afirmação no seio das sociedades católicas, foi, de facto, chamada a colaborar com uma instituição que se tornou cada vez mais dominante na regulação das relações sociais, na normalização das vivências e manifestações religioso-culturais e na domesticação dos costumes e da mentalidade. Num estudo mais descomprometido ideologicamente, o historiador jesuíta John W. O'Malley dá conta desta inapagável cumplicidade, salientando que o próprio Inácio de Loyola ofereceu o seu apoio a D. João III em ordem a alcançar a desejada obtenção da confirmação papal para a implantação definitiva do Tribunal da Inquisição em Portugal ${ }^{3}$. Este Tribunal tinha sido instituído provisoriamente em 1536, pela bula papal Cum ad nihil magis, e esperava a aprovação definitiva que foi conseguida da parte do Papa antes do fim da década de 40. No mesmo sentido de procura de distanciamento em relação às polémicas do passado, segue também esta nova linha hermenêutica o volumoso Dicionário Histórico da Companhia de Jesus, editado recentemente, depois de mais de 20 anos de preparação sob a direção de Charles E. O’Neil, s. j. e Joaquin M. Domínguez. Na extensa entrada dedicada ao Tribunal do Santo Ofício são apresentadas, com assinalável rigor e clareza, as relações de colaboração e de divergência entre ambas as instituições eclesiásticas ${ }^{4}$.

Estudiosos laicos portugueses da Inquisição, como Reis Torgal, colocam a tónica nas razões de ordem económica para explicar o empenho do Reino de Portugal em instituir no seu seio a Inquisição:

parecem não restar dúvidas que razões de natureza económico-social estiveram na base do esforço português com vista à instauração do Santo Ofício. Significou estruturalmente a intenção de o estatuto cristão-velho, representativo do decadente sistema económico feudal, apoiado pela burguesia tradicional e até pelo povo ideologicamente controlado, dominar o estrato cristão-novo e os seus meios económicos, que significavam no país a única força que realmente existia no sentido do capitalismo comercial de concorrência 5 .
Francisco Bethencourt, especialista da Inquisição em Portugal, complexifica, num quadro problematizante mais sofisticado, as razões que levaram à instalação do Tribunal do Santo Ofício no país, mas colocando na base dos motivos uma estratégia estatizante:

sem menosprezar as causas específicas, religiosas e sociais, do pedido de estabelecimento da Inquisição, decorrentes das pulsões arcaicas de tipo étnico, não podemos deixar de sublinhar que o pedido se insere numa estratégia de "naturalização" e "estatização" da Igreja, caracterizada pela intervenção crescente do poder régio na organização da hierarquia eclesiástica ${ }^{6}$.

É certo que Inácio de Loyola prestou junto do Vaticano um serviço que se revelou importante para a diplomacia portuguesa desempatar a indefinida procrastinação das negociações tendentes à confirmação definitiva da Inquisição portuguesa pela Cúria Romana ${ }^{7}$, o que acabou por acontecer em 1547 com a publicação da bula Meditatio Cordis de 16 de julho ${ }^{8}$.

Contudo, também é verdade que o primeiro geral da Companhia levantou dificuldades ao insistente convite de D. João III para que os Jesuítas fossem destacados para ocupar o cargo de inquisidores neste novo tribunal português. O provincial dos Jesuítas portugueses, Pe. Diogo Mirão, de origem espanhola, tinha acolhido, porém, esta proposta do Rei de forma efusiva, por entender que tal cargo se traduziria em maior prestígio para a Companhia, dada a má imagem social que

2 C. Dalmasès, Ignace de Loyola, le Fondateur des Jésuites (Paris: Le centurion, 1984), 40 e ss.; Mark Rotsaert, Ignace de Loyola et les Renouveaux spiritueles en Castille au début du XVI eme siècle (Roma: Centrum Ignatianum Spiritualitatis, 1982), 15 e ss. Ver ainda a obra importante de Cécil Roth, Histoire des Marranes (Paris: Liana Levi, 1990).

3 John W. O' Malley, s.j., The first jesuits (Londres: University Harvard Press, 1995), 310-20

4 J. L. González-Novalín, s.j., "Inquisición", in Diccionario histórico de la Compañía de Jesús. Biográficotemático, ed. Charles O’Neil, s.j. e Joaquín M. Domínguez, s.j. (Roma-Madrid: Institutum Historicum SJ-Universidad Pontificia Comillas, 2001), v. III, 2028-36.

5 Luís Reis Torgal, A Inquisição: "Aparelho repressivo e ideológico do Estado", Separata da Revista Biblos, 51, Coimbra, (1975): 637.

6 Francisco Bethencourt, "A Inquisição", in História Religiosa de Portugal, ed. Carlos Moreira Azevedo (Lisboa, Círculo de Leitores, 2000), v. 2, 99. E ver do mesmo autor a obra de caráter comparativo que já se tornou clássica para o estudo deste tribunal: História da Inquisição: Portugal, Espanha e Itália (Lisboa: Círculo de Leitores, 1995). Ver ainda os relevantes estudos de Maria José Ferro Tavares, Judaísmo e Inquisição: Estudos (Lisboa: Presença, 1987). Mais recentemente, ver José Pedro Paiva e Giuseppe Marcocci, História da Inquisição em Portugal - 1536-1821 (Lisboa: Esfera dos Livros, 2013).

7 Monumenta ignatiana (Madrid: Typis Gabrielis Lopez del Horno, 1904), 269 e ss.

8 Com esta bula da instituição definitiva da Inquisição em Portugal foi estabelecido juridicamente um instrumento poderoso de condução dos processos com proteção das testemunhas de acusação pelo sigilo, vedando aos réus a possibilidade de saberem quem eram os seus acusadores. Francisco Bethencourt, "Inquisição" in História religiosa de Portugal, ed. Carlos Moreira Azevedo (Lisboa: Círculo de Leitores, 2000), v. C-I, 447-48. 
tinham os cristãos-novos, e por lhe parecer uma grande vantagem o facto de, com o controlo do Santo Ofício pela Companhia, não se virem a suceder em Portugal as perseguições inquisitoriais à sua Ordem, como acontecia em Espanha9.

Era já antiga a má fama dos cristãos-novos em Portugal, mas dilatou-se ainda mais no século XVI com a entrada em cena do Tribunal da Inquisição. A propaganda antissemita teceu uma forte mentalidade antijudaica e ergueu um formidável mito oprobrioso em torno da raça hebraica. O coletor apostólico André Caligari apontava, em 1575, a macabra imagem que corria entre o povo de Portugal dos médicos de origem judaica: "Os médicos em Portugal, que são todos cristãos-novos, não fazem senão sangrar três, quatro e seis vezes os enfermos". E acrescenta, noutro passo, que corria a fama de os médicos terem confessado que "fizeram morrer uma infinidade de cristãos-velhos seus pacientes" 10 .

Assim como acontecia com o caso nascente do antijesuitismo, o antissemitismo fazia correr informações desfocadas e exageradas para denegrir a imagem da gente de nação. Recorde-se que, no exercício da medicina do tempo, era prática corrente o uso da técnica de sangrar os doentes, pois acreditava-se que era um meio de combater algumas doenças. Testemunha também o Padre Fernão Guerreiro, da Companhia de Jesus, numa carta escrita para Roma, que "a gente de nação dos cristãosnovos é por cá tão mal vista que falar num destes é falar numa coisa abominável e indigna de que os homens a vejam"11.

Apesar de uma comissão de avaliação da proposta do Rei português, nomeada em Roma por Inácio de Loyola, ter dado parecer positivo, o fundador dos Jesuítas, ainda que não quisesse desagradar ao monarca, fez saber das suas reservas em relação a tal aceitação e passou a decisão para o Papa. Neste impasse, o Rei acabou por nomear para inquisidor do Tribunal de Lisboa frei Jerónimo de Azambuja, tanto mais que o próprio cardeal D. Henrique não era então muito favorável à nomeação para o cargo de um membro da Companhia de Jesus.

Uma segunda proposta, para que os Jesuítas provessem alguns importantes cargos inquisitoriais do Santo Ofício, no quadro da expansão deste para outras cidades do país, em particular o projeto de fundação de um tribunal desta natureza em Coimbra, foi recusada por Inácio de Loyola, tendo este justificado a recusa pelo facto de as imunidades concedidas aos inquisidores, nomeadamente a dispensa do voto de obediência aos superiores da Ordem, serem incompatíveis com o estatuto religioso específico de um jesuíta. Mais tarde, o geral da Companhia de Jesus, Lainez, recomendou aos Jesuítas que não participassem da máquina inquisitorial e o visitador no Oriente, Alessandro Valignano, incluiu nas regras, por si elaboradas em 1588, a seguinte ressalva:

Deve o provincial proibir que os nossos assistam aos atos da Inquisição como inquisidores ou agentes ou comissários do Santo Ofício, ainda que nestas partes se concede que sejam os nossos consultores do mesmo Santo Ofício, sendo avisados que não se metam em mais do que convém e se lhes dá licença ${ }^{12}$.

Apesar dessas recomendações superiores, é muito frequente a presença de jesuítas entre aqueles que faziam sermões de auto de fé, qualificadores, verificadores, revedores (que realizavam as visitas às naus), comissários, deputados e promotores do Santo Ofício em Goa, assim como de outras ordens religiosas instaladas na Índia Portuguesa ${ }^{13}$. Como exemplo, podemos indicar que, do total de setenta e seis deputados e promotores da Inquisição de Goa até 1682, sessenta e um pertenciam a ordens religiosas - vinte dominicanos; dezassete jesuítas; onze agostinianos; dez franciscanos; e três de outras ordens -, enquanto os outros quinze eram funcionários de tribunais e de outras repartições do Rei (nove) e do clero secular (seis) ${ }^{14}$.

Nos tribunais do reino, essa tendência verificada no tribunal oriental não se repete. É verdade que se pode identificar representantes da Companhia de Jesus ocupando cargos como os de qualificadores, comissários, verificadores e revedores, além de participarem dos autos de fé pregando sermões, mas há poucos entre os deputados e promotores.

Também se deve levar em consideração que os registos acerca desses cargos e atividades são esparsos e lacunares, o que nos pode fazer incorrer em erro. Contudo, ao juntarmos informações pontuais de especialistas no estudo da Inquisição e de documentos guardados no arquivo da Torre do Tombo, algumas conclusões podem ser indicadas.

Francisco Bethencourt informa de que "há um grande número de indicações de religiosos da Companhia

\footnotetext{
9 Francisco Rodrigues, s.j., História da Companhia de Jesus, História da Companhia de Jesus na Assistência de Portugal (Porto: Apostolado da Imprensa, 1931), t. I, v. I, 252, 692 e ss.

10 "Cartas de Évora", 10 de março e de 16 de abril de 1575, ASV, Nunciatura portuguesa, 2, fls. $35-35 \mathrm{v}$.

${ }^{11}$ Carta de Angra, Açores, 2 de agosto de 1592, ARSI, Lus. 71, fls $195-195 \mathrm{v}$.

12 Ver "Sumário das regras para o provincial da Índia", in Documenta Indica, ed. José Wicki (Romae: Monumenta Historica Societatis Iesu, 1965), v. 14,850

${ }^{13}$ Segundo António Baião, A Inquisição de Goa: tentativa de história da sua origem, estabelecimento, evolução e extinção - introdução à correspondencia dos Inquisidores da Índia 1569-1630 (Lisboa: Academia das Ciências, 1945), v. 1. 178, no início da Inquisição eram os notários que ofereciam os libelos, depois os deputados assumiram também o papel de promotores. Portanto, não se fazia distinção destes cargos na Índia.

${ }^{14}$ António Baião, A Inquisição, v. 1, 167-75.
} 
de Jesus para o cargo de qualificadores"; no entanto, não dá números ${ }^{15}$. Mas, apesar da ausência de quantificação, trata-se de uma afirmação pertinente em relação às constantes referências que se possui a partir de biografias dos jesuítas.

Elvira Mea, ao estudar o tribunal de Coimbra ao longo do século XVI e início do XVII (precisamente, 1605) indica dominicanos e agostinianos para os cargos de inquisidores e deputados, sem nenhuma menção aos jesuítas, mas informa que os inacianos acompanhavam os deputados nas visitas às livrarias e às naus, sem falar no exercício do cargo de qualificador e na elaboração de sermão para auto de fé ${ }^{16}$.

Ao consultar as listas existentes em arquivos da Inquisição, sob a guarda da Torre do Tombo, percebe-se uma interessante tendência. No caso da Inquisição de Coimbra, por exemplo, no período desde sua criação até 1732, num total de duzentos e sessenta registos referentes aos nomes de seus deputados, apenas doze são identificados como clérigos regulares, sendo a grande maioria desses funcionários padres seculares. E, de entre aqueles que são regulares, não há nenhum jesuíta (sete dominicanos, três agostinianos, um franciscano e um beneditino) $)^{17}$.

No importante Conselho Geral, verificam-se noventa e dois registos de ministros, até 1705 , sendo mais uma vez a maioria de clérigos seculares. Há apenas treze regulares: onze dominicanos, um agostiniano e um jesuíta, o padre Jorge Serrão, indicado em $1579^{18}$.

A mesma tendência pode ser verificada na Inquisição de Évora. No período até 1730, num total de cento e dezessete registos, são indicados apenas dezassete clérigos regulares: treze dominicanos, três franciscanos e um jesuíta - o padre Manuel do Valle, indicado por volta de $1603^{19}$.

Nesta linha, Francisco Rodrigues esforça-se, na História da Companhia de Jesus na Assistência de Portugal, por relevar a colaboração de alguns membros da sua Ordem apenas nas tarefas de edificação espiritual, isto é, de pregação e de admoestação dos condenados pela Inquisição no sentido de se arrependerem de modo a livrá-los da pena capital. Um dos casos referidos foi o auto de fé celebrado em Évora no ano de 1560, em que saíram em procissão:

para cima de setenta penitenciados por diversos delitos e cinco condenados às chamas, três homens e duas mulheres, das quais uma, já sobre o cadafalso, confessou as culpas e alcançou o perdão. Acompanharam-nos o reitor da universidade, Leão Henriques, e mais quatro padres seus súbditos, e não deixaram de os aconselhar e esforçar, enquanto não terminou a longa e lastimosa solenidade. Só um dos supliciados expirou sem dar sinais de contrição ${ }^{20}$.
Destacando o papel querigmático e espiritual desempenhado pelos padres da Companhia em autos de fé, que apenas contribuíram, na sua ótica, para "suavizar" a condenação e até libertá-los de penas extremas, o referido historiador jesuíta salienta que mais nenhum cargo, ou cooperação, foi dado pela Companhia a esta instituição judicial:

O zelo de apóstolos e a caridade compassiva os levava a suavizar, quando em sua mão estava, as acerbas torturas de alma e corpo, que atormentavam aqueles desaventurados, nem exerciam na inquisição outros empregos durante o tempo que agora nos ocupamos, senão esse de pura misericórdia com os padecentes ${ }^{21}$.

\section{Participação dos Jesuítas na ação inquisitorial}

Sem querermos pôr em causa o pendor caritativo e espiritual da ação dos pregadores jesuítas no cenário horripilante das sessões públicas da execução das penas capitais do Santo Ofício, não se pode omitir que alguns dos seus membros tiveram, de facto, um papel ativo em termos conselheirísticos e de assessoria no processo de implantação, expansão e consolidação da Inquisição Portuguesa no século XVI, como pode ser comprovado com os dados apresentados, principalmente em relação ao tribunal goês, mas também com alguns exemplos históricos. Além do já referido contributo de Inácio de Loyola, o próprio Francisco Xavier também desempenhou um papel influente no sentido de elucidar o Rei D. João III sobre a importância da criação de um tribunal do Santo Ofício em Goa. Em maio de 1546 escrevia, neste sentido, a este monarca lamentando a falta de pregadores de que a Índia padecia, "porque, à mingua deles, [...] entre nós, os portugueses, vai muito perdendo-se a Fé". E acrescenta uma segunda necessidade existente naquela colónia, para a correção dos costumes e para depurar a contaminação da fé e combater os infiéis e o paganismo:

A segunda necessidade que a Índia tem para serem bons cristãos que nela vivem é que mande Vossa Alteza a Santa Inquisição, porque há muitos que vivem a lei mosaica e a seita mourisca,sem nenhum temor de Deus, nem vergonha do mundo. E porque isto são muitos e espalhados por todas as fortalezas, é necessária a Santa Inquisição e muitos pregadores ${ }^{22}$.

\footnotetext{
${ }^{15}$ Francisco Bethencourt, "A Inquisição", 114.

${ }^{16}$ Elvira Mea, A Inquisição de Coimbra no século XVI: a instituição, os homens e a sociedade, Doutoramento em História Moderna e Contemporânea, Faculdade de Letras da Universidade do Porto, Porto, 1989, v. 1, 384-90.

17 ANTT. Inquisição - Conselho Geral - Livro 258. fl. 7-19 v.

${ }^{18}$ Ibidem, fl. 125-133v.

${ }^{19}$ Ibidem, fl. 155-162.

${ }^{20}$ Francisco Rodrigues, s.j., História da Companhia de Jesus, 692.

${ }_{21}$ Francisco Rodrigues, s.j., História da Companhia de Jesus, 692-93.

${ }^{22}$ Epistolae S. Francisci Xavierii (Romae: Monumenta Historica Societas Iesu, 1944), t. I, 346-47.
} 
Entende-se este parecer de Francisco Xavier em consonância com a mentalidade eclesial dominante na época, em especial nas cristandades ibéricas, que via na Inquisição um instrumento importante para garantir a purificação da fé e a regulação da pureza dos costumes.

A Inquisição portuguesa só virá a expandir-se para Goa depois da morte de D. João III, por determinação do cardeal D. Henrique, a 20 de março de 1560, no período da regência de D. Catarina ${ }^{23}$. Em Goa, muitos padres jesuítas vieram a prestar serviços regulares à Inquisição ${ }^{24}$, quer como pregadores quer como deputados do tribunal ${ }^{25}$.

Também não é de descurar a assessoria dada pelo jesuíta Leão Henriques (1524-1589), professor da Companhia, ao cardeal D. Henrique na elaboração do primeiro Regimento do Santo Ofício, concluído no ano de $1552^{26}$. O texto foi preparado de forma minudente, revelando a preocupação de misturar o menos possível as esferas do poder temporal com o espiritual. Tratase de um texto legal caracterizado pela sua feição marcadamente eclesiástica. Este regimento fornece um quadro jurídico em que se acentua a subordinação desta instituição judicial ao Pontífice Romano, de modo a atenuar o seu caráter estatal, de que estava eivado desde a sua fundação em Portugal ${ }^{27}$.

Apesar de, no prólogo, o inquisidor-geral reconhecer a dependência em relação ao monarca português,

${ }^{23}$ Raul Rego, "Prefácio" in O Último Regimento e o Regimento da economia da Inquisição de Goa (Lisboa: Biblioteca de Nacional, 1983), 10 e ss.

${ }^{24}$ Segundo dados apurados entre 1760 e 1718 por António Baião, 20 por cento dos deputados que constituíram a Inquisição goesa foram jesuítas, embora isto não signifique que todos os Jesuítas fossem unanimemente a favor da participação e do modo de atuação deste tribunal. António Baião, ed., A Inquisição de Goa: Correspondência dos Inquisidores da Índia 1500-1630 (Coimbra: Imprensa da Universidade, 1930), cap. 3.

${ }^{25}$ Ver o trabalho de pesquisa estatístico e de análise da sociologia institucional sobre os indivíduos que proviam os cargos institucionais, bem como os que exerciam funções parenéticas. J. L. de Mendonça e A. J. Moreira, História dos principais Actos e procedimentos da Inquisição em Portugal (Lisboa: Imprensa Nacional/Casa da Moeda, 1980), 144 e ss. Neste quadro de cooperação, há que ter em conta alguns pronunciamentos inquisitoriais registados no Oriente, menos favoráveis à Companhia de Jesus, no âmbito das polémicas em torno das metodologias missionárias aplicadas pelos Jesuítas no processo de missionação do Malabar, do Japão e da China.

${ }^{26}$ Como também se deve lembrar o exercício do cargo de deputado da Inquisição de Évora e de Coimbra pelo provincial dos Jesuítas, Jorge Serrão, e que também exerceu as mesmas funções o menos conhecido Pe. Manuel Alvares Tavares. H.P. Salomon, Portrait of a new christian: Fernão Alvares Melo 1569-1632 (Paris: Fundação Calouste Gulbenkian, 1982), 73 e 111-12.

27 José Eduardo Franco e Paulo de Assunção, Metamorfoses de um polvo: Religião e política nos regimentos da Inquisição sécs. XVI a XVIII (Lisboa: Prefácio, 2004), 16.

${ }^{28}$ Francisco Bethencourt, "A Inquisição", 99.

${ }^{29}$ Sebastião Gonçalves, Primeira Parte da História dos Religiosos da Companhia de Jesus e do que fizeram com a divina graça na conversão dos infiéis a nossa sancta fee catholica nos reynos e provincias da India Oriental composta pello Pe. Sebastiam Gonçalves religioso da mesma Companhia, português, natural de Ponte de Lima (Coimbra: Atlântida, 1960, v. 2, 321-22. a longa direção henriquina à frente deste tribunal acentuou a tendência autonomizante, o que é revelador de que a instrumentalização da Inquisição ao serviço de uma "estratégia política acabou por não dar os frutos pretendidos".

Pois, como conclui Bethencourt, se a burocracia inquisitorial assumiu uma posição determinante no seio da Igreja em Portugal, saindo das suas fileiras muitos dos novos bispos, sobretudo nos séculos XVI e XVII, o Santo Ofício acabou por se revelar bastante mais autónomo do que desejariam D. Manuel e D. João III (autores do projeto), causando problemas, a longo prazo, à política régia. Aliás, essa política face à Inquisição ou à diversidade de sensibilidades religiosas sofreu alterações conforme os reinados e a orientação dos grupos de poder ${ }^{28}$.

Aliás, a figura do padre Leão Henriques foi tão importante e destacada que foi retratada de forma curiosa por Sebastião Gonçalves, um jesuíta que escreveu, no início do século XVII, uma história da Companhia de Jesus no Oriente. Foi apresentado como um inquisidor, como se pode ver no trecho a seguir:

Os inquisidores sempre tiveram companheiros, de modo que de ordinário há dois inquisidores, os quais têm deputados que costumam ser de diversas religiões. Da Companhia muitas vezes havia dois; da mesma Religião tomam os inquisidores varões doutos que preguem nos cadafalsos. O Pe. Antonio de Quadros, nosso provincial, pregou por vezes; o Pe. Provincial Ruy Vicente, o Pe. Visitador Nicolau Pimenta, o Pe. Pero Francisco e o Pe. Doutor Antonio Fernandez. Tem o Santo Ofício promotor, meirinho, secretários, guardas, porteiro e familiares. O reitor do colégio de São Paulo tinha por ofício rever os livros. Fora de Goa costumavam os padres da Companhia em muitas partes ser comissários do Santo Ofício. E assim como São Pedro da Ordem dos Pregadores padeceu martírio sendo inquisidor, assim o Pe. Antonio de Quadros houvera de ser morto pelo médico que o curava, se o boticário abexim não conhecera a purga ordenada para sua morte; e o Pe. Belchior da Fonseca sendo comissário em Bengala morreu de peçonha que lhe deram por fazer este ofício. Em Portugal foi Leão Henriques um dos inquisidores da mesa grande, a quem sucedeu o padre Jorge Serrão, e ambos eles foram provinciais ${ }^{29}$.

Este registo possui grande interesse, uma vez que sabemos que Leão Henriques não foi inquisidor, assim como o outro jesuíta referido, o padre Jorge Serrão. Tanto um quanto o outro participaram como ministros do Conselho Geral, conforme informado anteriormente para o segundo caso. Assim, percebe-se que Sebastião Gonçalves não tinha aparentemente constrangimento algum em aproximar intimamente a Companhia de Jesus 
da Inquisição, chegando mesmo a exagerar o desempenho de um seu companheiro. É bem verdade que os dois jesuítas por ele citados foram realmente influentes figuras junto do Santo Ofício, mas não figuraram como inquisidores. Sabe-se inclusive que Leão Henriques nunca aceitou as honras do cargo que exerceu ${ }^{30}$. Ou seja, esse trecho serve para demonstrarmos que entre os companheiros de Jesus não havia uma única opinião sobre o papel do tribunal inquisitorial. Por seu lado, os Jesuítas foram chamados várias vezes a dar uma colaboração valiosa enquanto peritos em assuntos doutrinais numa categoria importante chamada qualificador do Santo Ofício. O qualificador tinha por função "dar parecer sobre livros apreendidos ou sobre declarações de presos e conteúdo de denúncias"31. Tais apreciações técnicas tinham um peso significativo na instrução das decisões judiciais.

A ocupação de vários cargos inquisitoriais por parte dos Jesuítas não significa necessariamente que tivesse havido uma total e unânime identificação da Inquisição com a Ordem de Loyola, nem sequer que tivesse existido sempre estreiteza de relações e sintonia plena de objetivos. Nem sequer significa que, em geral, os Jesuítas tivessem procurado avidamente ocupar cargos inquisitoriais. Muitas vezes, assiste-se prevalecentemente à manifestação de sentimentos de relutância em detrimento de uma concordância entusiástica na aceitação de tarefas nos Tribunais do Santo Ofício. Outras ordens, de facto, têm uma tradição de maior expressão, como é o caso dos Dominicanos, no comando dos destinos da Inquisição portuguesa, bem evidente no maior número de cargos exercidos (e de maior importância diretiva, como indicado anteriormente) nesta instituição judicial. Além do pouco entusiasmo manifestado por Inácio de Loyola em aceitar que os seus religiosos assumissem cargos no Santo Ofício, também se conhecem casos de relutância de outros jesuítas, em consonância com o espírito do Fundador, em aceitar de bom grado este tipo de funções.

O visitador da Companhia de Jesus no Oriente, Alessandro Valignano, chegou a opinar que não era conveniente que os Jesuítas estivessem integrados na hierarquia inquisitorial, embora fosse, de certo modo, natural que alguns jesuítas, em virtude da sua qualificação teológica e jurídica, fossem requisitados para arguirem processos judiciais do Santo Ofício ${ }^{32}$. A este parecer não deixa de estar subjacente uma inteligente visão estratégica, que se liga com a questão das prioridades definidas constitucionalmente para a Companhia de Jesus, mas também a que não é alheia a questão da imagem social. Ou seja, tanto Santo Inácio como Valignano sabiam muito bem que a Inquisição não era propriamente uma instituição socialmente simpática, antes criava facilmente à volta de si anticorpos. Um envolvimento demasiado estreito dos Jesuítas na hierarquia inquisitorial e na sua missão de vigilância e punição não deixaria de trazer prejuízos para a fama da Companhia de Jesus.

Em termos do discurso, os dirigentes jesuítas mais notáveis tenderam a ver a colaboração com o Santo Ofício como um serviço que extravasava e até violava os princípios orientadores da sua Ordem. Casos houve em que estas funções também foram impostas aos Jesuítas, apesar do seu desacordo. Situação paradigmática desta imposição foi a do Pe. Manuel de Sá que, ao chegar a Goa em 1711, vindo de Portugal, para trabalhar nas missões indianas da Companhia, foi informado de que já tinha sido nomeado para deputado do tribunal local da Inquisição. Apesar do seu protesto, no qual alegava que o cargo era incompatível com as orientações da Companhia de Jesus e do Papa a esse respeito, foi coagido pelo inquisidor-mor a exercê-lo. Um ano depois, a mesma nomeação recaiu sobre um seu confrade, o Pe. José Pereira, que opôs as mesmas objeções, mas agora com o apoio do provincial dos Jesuítas de Goa. Mas a rejeição pura e simples daquelas funções implicava uma desobediência grave na perspetiva inquisitorial, dado que o inquisidor-mor contra-argumentava que detinha um poder delegado do Pontífice Romano para fazer aquela nomeação, insinuando que desobedecer-lhe equivalia a desobedecer ao Papa $^{33}$.

Porém, em geral, podemos concluir que as relações entre a Companhia de Jesus e o Santo Ofício decorreram, salvo exceções particulares, sem grandes sobressaltos e até com alguma significativa cumplicidade e cooperação ${ }^{34}$ no período que dista da sua implantação em Portugal até sensivelmente à proclamação da restauração da independência do reino, em 1640. Embora se tenha vindo a engendrar um clima de perturbação mais latente do que visível, especialmente nos últimos anos do regime filipino, devido à caução dada por alguns jesuítas à causa dos cristãos-novos e às apreciações desfavoráveis tecidas por alguns padres da Companhia aos estilos da Inquisição, prenunciadoras de críticas mais contundentes, que serão feitas no período da Restauração, não se registou nenhum confronto sério entre as duas instituições. Por

\footnotetext{
${ }^{30}$ Charles E. O’Neill e Joaquín Dominguez, eds., Diccionario Histórico, v. 2, 1899-1900.

31 Charles E. O’Neill e Joaquín Dominguez, eds., Diccionario Histórico, v. $1,114$.

32 Alexandre Valignano, "Sumário das normas para a Província da Índia, abril de 1588", in Documenta indica, v. 14, 849-50.

33 ARSI, Goa 9, II, fls. 529-532 e 546-550 e 36, II, fl. 310.

34 Registaram-se até algumas situações em que a Inquisição atuou em favor da salvaguarda da imagem da Companhia de Jesus, em casos em que foi aviltada pelos seus adversários. Tal como aconteceu, por exemplo, em 1615, tendo ordenado a recolha e um inquérito rigoroso a um papel antijesuítico, atribuído a um lente de Anatomia da Universidade de Coimbra, intitulado Razões que o Dr. João Bravo Chamiso, lente de Anatomia d'esta universidade e vereador do corpo d'ela fez sobre os Padres da Companhia, ANTT, Inquisição de Coimbra, processo no 1427 , fl. 148 .
} 
exemplo, em 1630, aquando da visitação às inquisições de Portugal feita pelo novo inquisidor-geral D. Francisco de Castro, são apresentadas queixas dos Miranda, residentes no colégio do Espírito Santo daquela cidade. O seu documento crítico constitui um "terrível libelo" contra a prática judicial da Inquisição. Denuncia a crueldade das torturas inquisitoriais nos cárceres do Tribunal, a desumanidade em relação aos familiares dos presos, em particular às crianças, deixando-as desamparadas e sem meios de sustento, pois mal os cristãos-novos ou outros eram acusados e presos, imediatamente os seus bens eram confiscados $^{35}$

\section{Conflitos no século XVII}

No século XVII, podemos detetar importantes focos de desgaste entre a Inquisição e a Companhia de Jesus, no Oriente. João Delgado Figueira - no tempo em que era promotor do Tribunal do Santo Ofício na cidade, uma vez que posteriormente viria a ser um dos inquisidores de Goa, nomeado em 1626 - foi protagonista de um forte atrito entre a Inquisição e os Jesuítas. O centro do problema residiu na discussão sobre os ritos gentílicos defendidos pelo padre Roberto Nobili como sinais exteriores e inofensivos à fé católica. Os debates já se desenvolviam desde 1610, quando, em 1618, o Papa Paulo V ordenou que o arcebispo e os inquisidores de Goa fizessem uma junta para analisar as práticas do jesuíta italiano no Malabar. Em 31 de janeiro de 1619, foi instalada a comissão formada pelos arcebispos de Goa e Cranganor e pelo promotor da Inquisição João Delgado Figueira. O propósito da junta era tomar "perfeita informação se os ritos dos brâmanes e a linha e o sendi e o sândalo e uso de lavatórios são sinais da falsa seita dos ídolos"36.

Logo o primeiro registo refere-se ao arcebispo de Cranganor, que apresentou à junta um "tratado comprido" sobre a natureza dos ritos gentílicos, recomendando que fosse lido por teólogos. Além disso, havia livros trazidos de Maduré, mas que só ele e o padre Nobili saberiam ler. O arcebispo de Goa solicitou então que eles lhes contassem o que havia nos livros. O jesuíta italiano foi o primeiro a falar e defendeu o caráter político dos ritos gentílicos ${ }^{37}$. No dia 9 de fevereiro de 1619 , o arcebispo de Cranganor enviou uma carta à comissão, na qual declarou que ele e os padres da Companhia de Jesus sabiam, "de vista e experiência de muitos anos e da lição dos livros e línguas dos brâmanes", que a linha, o sândalo e os lavatórios eram sinais da nobreza das famílias brâmanes. Reforça, assim, a defesa de Nobili ${ }^{38}$. Entretanto, havia quem discordasse. Uma carta do bispo de Cochim, datada de 6 de junho de 1619, usa o mesmo argumento da experiência para denunciar, de forma veemente, os ritos gentílicos, ao afirmar que "há trinta e cinco anos e seis meses que vim para a Índia [...] e pela experiência que tenho destas partes [...] tenho sabido que a linha é sinal demonstrativo de gentilidade e de religião falsa que os brâmanes gentios professam" ${ }^{39}$. João Delgado Figueira articulou os seus trabalhos apresentando primeiramente um arrazoado sobre a questão, enumerando as dúvidas enviadas pelo Papa, e, depois, contrapondo argumentos contra e a favor dos ritos gentílicos. Desdobrou as dúvidas em dois níveis: "se é lícito" e "se é necessário" o uso dos ritos gentílicos. Afirmou, logo a princípio, que não era lícito, sem mais delongas, por serem evidências de ligação com a religião dos gentios, mas dedicou-se em seguida à análise da necessidade da permissão do uso dos ritos para o bem da conversão. Concluiu dizendo que "os ditos sinais de protesto da gentilidade oriental são sinais muito pertencentes à religião dos ditos pagodes e não convém que se permitam na Cristandade", enfatizando o caráter diabólico dessas manifestações ${ }^{40}$.

Trata-se de um texto elegante, extremamente erudito, que demonstra o grande conhecimento da realidade indiana que tinha João Delgado. Além desse parecer, ou voto que ficou nos registos da Inquisição -, elaborou ainda um outro em latim, datado de 10 de abril de 1619, com cópias despachadas para Roma e para o Conselho Geral do Santo Ofício em Lisboa; são oitenta e seis folhas, nas quais o promotor desenvolve as ideias já expostas ${ }^{41}$. No entanto, não se restringiu à construção de uma argumentação contra os ritos gentílicos. Em 1620, recebeu um texto de cinco padres brâmanes, vigários de igrejas de Goa, que afirmavam "ser a linha e curumbim sinal de seita". Nele, os clérigos seculares nativos explicavam que:

a linha de que é a questão ordinariamente se faz de nove fios porque têm os brâmanes para si, e de opinião que corre entre eles, que o mundo se reparte em nove partes, e desses nove fios se fazem três cordéis delgados, os quais lançam ao tiracolo do ombro esquerdo ao modo de colar como um só. Estes três cordéis, em protestação dessa divindade falsa que adoram, têm um só nó porque dizem que estas três falsas pessoas são Brama, Visnnú, Mtayesou; compondo de nove fios para mostrar que todas as criaturas destas nove partes do mundo estão sujeitas a estes falsos deuses que adoram ${ }^{42}$.

\footnotetext{
35 António Borges Coelho, Inquisição de Évora, 1533 a 1668 (Lisboa: Caminho, 1987), 209-34.

36 ANTT. Conselho Geral do Santo Ofício. Liv. 207. Consultas da Inquisição de Goa (1572-1620). fl. 52

37 Ibidem. fl. 61.

${ }^{38}$ Ibidem. fl. 64.

39 Ibidem. fl. 79.

${ }^{40}$ Ibidem. fl. 83-96.

${ }^{41}$ ANTT, Conselho Geral do Santo Ofício, Liv. 474, Parecer de João Delgado Figueira, promotor e deputado da Inquisição de Goa sobre os sinais gentílicos, Goa, 10 de abril de 1619, 86 fls.

42 ANTT, Conselho Geral do Santo Ofício, Liv. 207. Consultas da Inquisição de Goa (1572-1620), fl. 98.
} 
Relataram ainda que a linha era posta pelo sacerdote hindu, o boto, o que implicava necessariamente frequentar uma série de cerimónias gentílicas. Por fim, desautorizaram completamente a interpretação defendida por Nobili e pelo arcebispo de Cranganor, alertando para "o perigo de escândalo para a Cristandade". Após este episódio, no mesmo ano, João Delgado Figueira convocou vários portugueses para se apresentarem à Inquisição: civis (11) e religiosos (2), que habitavam há muito tempo na cidade de Goa, e clérigos seculares nativos (7) de várias paróquias da cidade e arredores (inclusive Bardez e Salcete). A todos fez a mesma pergunta: "Se sabiam o significado da linha". Todos responderam que sim, e todos, sem exceção, disseram que ela era sinal de seita gentílica.

Não é difícil perceber o objetivo do promotor: tratava-se da construção de um argumento bem alicerçado para defender a objeção aos métodos de cristianização de Nobili, destacando a possibilidade de escândalo que a permissão do uso dos ritos gentílicos poderia causar à cristandade sitiada da capital ${ }^{43}$. O empenho de João Delgado Figueira em desautorizar os métodos de cristianização de Nobili no Malabar deve ter-lhe angariado muitas antipatias, além de outras já apresentadas até aqui. As considerações dessa junta foram remetidas ao inquisidor-geral em Lisboa, D. Fernão Martins de Mascarenhas, para dar uma sentença, que, por sua vez, a enviou a Roma, onde a questão foi examinada por três teólogos, que deram razão a Nobili. Baseado em todas essas considerações o Papa Gregório $\mathrm{XV}$, na bula Romanae sedis antiste, de 1623 , permitiu a continuidade dos trabalhos do jesuíta italiano, fazendo algumas recomendações para que a superstição e o escândalo fossem sempre evitados. Além disso, aprovou a separação das castas, mas recomendou que nada fosse feito em prejuízo dos mais pobres e humildes.

Apesar dessa decisão do Papa, a questão não foi definitivamente superada. $\mathrm{O}$ maior problema residiu na reação de outras ordens que, no final do século XVII, acabaram por denunciar que os Jesuítas permitiam a prática de "usos gentílicos". A disputa resultante destas denúncias ficou conhecida como querela dos ritos malabares, que veio a ser associada à questão dos ritos chineses. A polémica continuou e só conheceu desfecho no século XVIII, quando Bento XIV, em 1742, publicou a bula Ex quo singulari, na qual condenou os ritos chineses como supersticiosos, sendo que, em 1744, publicou a bula Omnium sollicitudinum, que resolveu o mesmo sobre os ritos malabares, dando assim razão aos inimigos dos Jesuítas. Os exemplos aqui apresentados servem para percebermos que a partir do século XVII, em vários campos houve sérios atritos entre a Companhia de Jesus e a Inquisição, com intuito de reforçar a afirmação de que muitas vezes essas duas instituições de caráter religioso disputavam espaço e poder de influência no Império Português.

Alguns incidentes no próprio reino de Portugal tinham, entretanto, atiçado novamente a corrente antijudaica, que instigou várias manifestações populares a favor da Inquisição e do reforço do seu aparelho repressivo contra a "astúcia" e a "perfídia" semitas. O mais grave acontecimento foi o protesto e a perseguição desencadeada contra os cristãos-novos de origem judaica, na sequência de um roubo de vasos sagrados, executado na igreja do Mosteiro de Odivelas, em Lisboa, por um rapaz hebreu que, além do furto, teria cometido o sacrilégio de fazer estragos sobre o altar, no mês de maio de 1671 . Embora o rapaz acabasse por ser capturado, torturado e exemplarmente executado, a comunidade judaica não deixou de ser responsabilizada coletivamente pelo sucedido, sendo alvo de vários motins, incitados pelos pregadores pró-inquisitoriais.

O próprio D. Pedro II, pressionado pela opinião pública revoltada que exigiu ao Santo Ofício medidas severas contra os implicados no referido ato sacrílego, aceitou a captura de 90 comerciantes ricos. Uns foram presos e outros exilados nas cidades do interior, em particular na Guarda. Restauraram-se medidas repressivas e infligiram-se penas à altura da enfatizada gravidade do acontecimento ${ }^{44}$. O Tribunal aproveitou-se da situação para recobrar força e prestígio, tanto mais que a população, escandalizada com o sacrilégio, queria ver justiça feita ${ }^{45}$. Numa tentativa de contrariar esta ameaça que pairava sobre os cristãos-novos portugueses, Manuel da Gama de Pádua, um cristão-novo muito rico, dirigiu-se para Roma a fim de tentar obter a proteção do bispo da cidade papal. Aí, recebeu o apoio dos Jesuítas para a sua

\footnotetext{
${ }^{43}$ Ibidem, fl. 292-302.

${ }^{44}$ A primeira resposta, impulsiva, do monarca para satisfazer a população amotinada e escandalizada com o ato sacrílego tinha sido a publicação do decreto de 22 de julho de 1671, que mandava expulsar de Portugal todos os penitenciados da Inquisição desde o último perdão geral de 1605 e os que também tivessem saído em auto de fé. Esta ordem de expulsão também era extensível aos seus filhos e netos. ANTT, Armário jesuítico, maço 29, n. 13. Mas o decreto acabou por não ser aplicado devido aos inconvenientes de tal execução que foram dados a antever a D. Pedro II. Não foi menor o papel elucidativo e de apelo à reconsideração do seu confessor jesuíta. Alexandre da Paixão, Monstruosidades do tempo e da fortuna 1662-1680 (Barcelos: Companhia editor do Minho, 1939), v. 2,122 . Esta obra escrita naquela época desaprova o apoio dos Jesuítas, em particular do padre António Vieira, às reivindicações e pretensões dos indivíduos de raça judaica. No volume III, o autor desta espécie de crónica político-social daquele tempo manifesta um forte antissemitismo de contornos mitificantes, que partilha do mito do complot judaico, ao afirmar que o Reino de Portugal estava contagiado com as mais nocivas das partes, "o pestífero sangue desta maldita gente". Alexandre Paixão, Monstruosidades, 50. Ver ainda João Lúcio de Azevedo, História dos Cristãos-Novos (Lisboa: Clássica, 2008), 239.

45 João Lúcio de Azevedo, História do Padre António Vieira (Lisboa: Clássica, 1992) 120 e ss.; Tristão da Cunha de Ataíde, Portugal, Lisboa e a corte nos reinados de D. Pedro II e D. João V: Memórias históricas, eds., António Vasconcelos de Saldanha e Carmen M. Radulet, (Lisboa: Chave Ferreira, 1990).
} 
causa, em particular a colaboração do seu velho amigo Padre António Vieira, que lá se encontrava, desde 1669, em "peregrinação".

Os intentos de Manuel da Gama foram ao encontro dos interesses do provincial dos Jesuítas da Província do Malabar, o Pe. Baltazar Costa, que se encontrava em Roma para pedir assistência para sua província, duramente lesada pelas conquistas holandesas de 1660, com quem Vieira pôs em contacto o cristão-novo português. O Pe. Baltazar acreditava na possibilidade de Portugal vir a recuperar os territórios perdidos na Índia a favor da França e da Holanda.

Das conversações com os Jesuítas, resultou uma proposta que servia os interesses dos Jesuítas e dos Judeus, a qual precisava de receber o aval do Rei D. Pedro de Portugal. Manuel da Gama propunha à coroa portuguesa a constituição de uma companhia comercial com capitais cristãos-novos, decalcada do modelo da companhia do Brasil, para relançar o comércio de Portugal com a Índia. A contrapartida seria a esperada: o perdão geral de Roma para todos os membros da comunidade cristãnova portuguesa ${ }^{46}$. Neste acordo foram envolvidos a Universidade de Évora, o confessor jesuíta de D. Pedro, a rainha e alguns prelados portugueses que se uniram para pedir à Santa Sé a concessão do perdão ${ }^{47}$. O Rei de Portugal e a Santa Sé mostraram abertura para encontrar uma solução conciliadora ${ }^{48}$. Mas, em março de 1673, os responsáveis pela Inquisição portuguesa quiseram ver, no plano gizado pelo jesuíta, heresia e traição, e foram do parecer que a recuperação da Índia tinha menos valor do que manter a pureza da fé religiosa em Portugal.

Os correligionários deste Tribunal complementaram estes pronunciamentos com outras técnicas mais persuasivas para fazer vingar o seu ponto de vista. Organizaram manifestações populares contra o judaísmo e a Companhia de Jesus. Turbas populares assanhadas gritaram palavras de ordem contra os Jesuítas, foram afixados cartazes com mensagens ameaçadoras nas portas dos colégios e residências da Companhia de Jesus, com particular destaque para São Roque ${ }^{49}$.

\footnotetext{
${ }^{46}$ Luís de Menezes, História de Portugal Restaurado (Lisboa: Oficina de Miguel Deslandes, 1698), v. 2, 468 e ss.

47 ANTT, Armário jesuítico, maço 29, n.os 18 e ss.

48 Richard Graham, The jesuit António Vieira and his plan for the economic rehabilitation of seventeenth-century Portugal (São Paulo: Secretaria da Cultura, Ciência e Tecnologia, 1978), 179 e ss.

49 Jayme Constantino de Freitas Moniz, ed., Corpo diplomatico portuguez, contendo os atos e relações politicas e diplomaticas de Portugal com as diversas potencias do mundo desde o século XVI até aos nossos dias (Lisboa: Typ. da Academia Real das Sciencias, 1898), t. XI, v. XIV, 153 e ss.

50 Roque Monteiro Paim, Perfidia judaica, Christus vindex, manus principis Ecclesiae ab apostatis liberata (Madrid: s.ed., 1671).

51 Richard Graham, The jesuit, 182 e ss.

52 Alexandre da Paixão, Monstruosidades, 62.

53 ANTT, Armário jesuítico, maço 30, n. 84.
}

Alguns mentores influentes, por detrás destas manifestações, chegaram a propor soluções drásticas para o problema que encareciam em termos da sua gravidade. Um deles foi Roque Monteiro Paim, próximo de D. Pedro II e que viria a ser seu secretário particular. Este antissemita redigiu um texto polémico, caracterizado pela sua radical intolerância, cujo título é bem indicativo do conteúdo: Perfídia judaica.

Neste texto, defendia a expulsão de todos os judaizantes, a restrição e a maior vigilância da comunidade cristã-nova, a proibição dos casamentos mistos e a anulação de todos os privilégios e honras concedidos aos descendentes de Judeus. Afirmava com ênfase temerária e alarmista que, sob a cumplicidade jesuítica, os Judeus tinham facilmente aumentado de forma assustadora em Portugal, de tal modo que não haveria, a breve trecho, se assim continuasse a suceder, cristãos-velhos para os julgar $^{50}$. Um oficial do Santo Ofício chegou ao ponto de apelar para que a Igreja dos Jesuítas fosse purificada pelo fogo, alegando que estava a produzir heréticos, solicitando também que o confessor régio fosse queimado vivo $^{51}$. Hereges, renegados, educadores de hereges e pagãos, traidores eram os epítetos que o movimento próinquisitorial lançava contra os membros da Companhia de Jesus, vista, assim, como uma perigosa "ordem Protestante" no seio da Igreja Católica. "Com o apoio dos Jesuítas", afirmava um verso de um poema anónimo então difundido, "em menos de poucos dias, todos nos tornaremos Judeus" 52 . E alguns mendicantes quiseram ver justificadas as suspeitas tradicionais no tocante à natureza desta Ordem, donde não poderia sair coisa boa ${ }^{53}$.

Alguns prelados deram voz à defesa da causa da Inquisição, entre eles o arcebispo de Évora, que pediu a D. Pedro para não proteger os heréticos e apóstatas, e o bispo de Leiria, que alegava, em defesa da posição repressiva, que, quando a coroa tinha favorecido os cristãos-novos, Portugal havia sofrido revezes nas suas conquistas e nos seus interesses coloniais. Queria com isto significar que os cristãos-novos eram a raiz de todas as graves dificuldades. Mas apesar do retrocesso que este ambiente representava para as pretensões jesuíticas, um novo facto surgiu em seu favor: a prisão e a execução de duas freiras em Évora, que se afirmaram inocentes até à morte.

Esta execução, feita com base em acusações de testemunhas protegidas ao abrigo do segredo inquisitorial, foi usada por António Vieira como prova exemplar do modo de proceder da Inquisição Portuguesa. Na epistolografia de António Vieira desta época está bem presente a força do seu fogo crítico, que denunciava de forma aguda a triste situação da sociedade portuguesa subjugada pela Inquisição. Vieira sabia e dizia que este tribunal "matava inocentes". Tal era a má fama da Inquisição Portuguesa em Itália que, numa carta escrita de Roma, informa que 
naquela capital do catolicismo "corria a notícia de que, se alguém era inocente, que o mandassem para Portugal para logo o queimarem".

O pregador já tinha apontado em vários documentos o ambiente de espionagem doentia que corroía o tecido social português. Numa carta que é atribuída a Vieira, reproduzem-se algumas das suas críticas: "Em Portugal não se abre uma porta nem se fecha sem que toda a terra o não saiba". E ridiculariza ao extremo a inconsistência das acusações que se alegavam para condenar os cristãosnovos: "Quando queimaram um judeu, inocentemente acusado de ter assado o carneiro pascal, não faltou quem confessasse tê-lo visto levar o carneiro na algibeira, assá-lo ao lume de candeia e depois engolir o candeeiro"54.

O caso referido foi levado pelo jesuíta ao conhecimento da Santa Sé. Perante isto, o Papa vituperou os procedimentos judiciais do Santo Ofício português e decretou a suspensão do seu funcionamento judiciário por tempo indeterminado, no ano de $1674^{55}$. E um ano depois António Vieira alcança ainda, oficialmente, do Pontífice Romano, a imunidade contra a Inquisição Portuguesa e a anulação da sentença proferida em 1668 por este tribunal contra $\mathrm{si}^{56}$.

54 "Carta que o Padre António Vieira, estando em Roma da primeira vez, escreveu a um português e grave que também lá se achava sobre o rigor de estilo das Inquisições em Portugal naquele tempo", BA, cód. 49-IV-2. Ver a edição desta carta na recente edição da Obra Completa do Padre António Vieira na seção dos textos de autoria duvidosa: Padre António Vieira, Cartas e Papéis Vários, in Obra Completa, Ana Lúcia Machado e José Carlos Lopes de Miranda, eds. (Lisboa: Círculo de Leitores, 2014), t. I, v. V, 120-141.

55 Clemente X, pelo Breve de 3 de outubro de 1674, favorece declaradamente as pretensões dos cristãos-novos: ordena aos inquisidores que cessem totalmente os autos de fé e que suspendam qualquer atividade judicial e chama a si o julgamento das causas pendentes no Santo Ofício português. ANTT, Armário jesuítico, caixa 1, n. 51; e BPE, cód. CX/1-1. Em contrapartida, uma junta reunida por D. Pedro emitiu pareceres contra a determinação papal, que considerava lesiva dos direitos adquiridos pelo Santo Ofício português. Todavia, a influência do Pe. Manuel Fernandes conseguiu evitar que fossem tomadas medidas mais radicais em relação a esta intromissão radical da Santa Sé em assuntos portugueses. De qualquer modo, a obediência à suspensão papal não foi imediata, pois as portas do palácio da Inquisição só se fecharam efetivamente em março de 1678, acatando um novo Breve, agora do Papa Inocêncio XI. ANTT, Armário jesuítico, caixa 2, n. 304; e J. Vaz de Carvalho, "António Vieira em conflito com a Inquisição", in Brotéria, v. 145, n. 4/5, (1997), 389. A Santa Sé tinha exigido que fossem enviados para Roma dois processos inquisitoriais para averiguação pelos tribunais da Cúria Romana, exigência que foi sucessivamente desobedecida. Só em 1681 o Santo Ofício cede neste braço de ferro, enviando para o Vaticano os processos pedidos. Então, o Papa aceita restabelecer a Inquisição Portuguesa em funções plenas, no dia 23 de agosto daquele ano, ordenando que os reclusos fossem tratados com caridade, que se atenuasse o rigor das prisões, que os réus tivessem direito a assistência espiritual e a os sacramentos e lhes fosse facultada a leitura de obras espirituais. ANTT, Armário Jesuítico, caixa 2, n. 85.

56 Através do Breve de 17 de abril de 1675, o Papa Clemente X imuniza António Vieira em relação ao poder da Inquisição Portuguesa, tornando-o apenas subordinado à Congregação do Santo Ofício de Roma. No mesmo documento exalta-lhe o "zelo da Fé Católica, a ciência nas Letras Sagradas, a bondade de [...] vida e costumes, e outros louváveis merecimentos e bom proceder". António Vieira, s.j., Obra Completa, Tomo I, v. V, 175.
Entretanto, a Inquisição entrará novamente em pleno funcionmento passados menos de 7 anos nos inícios da década de 80, com mudança de Papa em Roma e cedendo a Santa Sé às pressões dos setores inquisitoriais portugueses.

\section{Considerações Finais}

As relações entre os Jesuítas e o Tribunal do Santo ofício vão continuar menos conflituosas e com a mesma postura da parte da Companhia até à segunda metade do século XVIII, ou seja, entre a colaboração e um certo distanciamento especialmente mantendo a posição de não ocupar lugares cimeiros da hieraquia inquisitorial.

A propaganda estatal pombalina publicada para justitificar a expulsão dos Jesuítas de Portugal em 1759, juntamente com a legislação reformista do governo de D. José I, nomeadamente a reforma da Inquisição, vai associar intimamente os Jesuítas ao passado pré-iluminista deste Tribunal. Particularmente, o Regimento Pombalino, que pretendeu reformar o Tribunal do Santo Ofício à luz de critérios da política assente no ideário do absolutismo iluminista, vai fundamentar o necessidade de reformação e estatização total desta instância judicial no facto desta ter sido tomada no passado pela influência dita "nefasta" dos Padres da Companhia. Essa hiperligação com a acusação que é feita por Pombal de uma liderança oculta dos Jesuítas servia mais os interesses da legitimação da política pombalina do que a atenção à efetiva história deste tribunal, que tinha sido mais complexa do que a visão mitificada e simplificada da ação dos Jesuítas fazia.

Os Jesuítas participaram na ação da Inquisição e da sua consolidação deste Tribunal como outras ordens e membros do clero secular o fizeram. O Tribunal do Santo Ofício afirmou-se como uma instituição que grangeou significativo consenso na sociedade portuguesa. $\mathrm{O}$ tema da Inquisição e da participação dos membros da Ordem de Santo Inácio nas estruturas deste Tribunal não reuniu, contudo, consenso dentro da Companhia desde os primórdios. Todavia, apesar das cautelas tomadas pelo fundador dos Jesuítas em relação à participação na Inquisição dos seus confrades, secundado nesta posição por altos responsáveis que lhe sucederam, diversos Jesuítas acabaram por ser chamados a participar ora como qualificadores, ora como assessores, pregadores e visitadores deste tribunal, fosse por obrigação ou mesmo por entenderam a mais valia desta instância judicial para o salvaguarda da identidade doutrinal da fé.

De qualquer modo, a documentação que chegou até nós permite-nos constatar o surgimento, especialmente no século XVII, de vozes críticas protagonizadas por membros da Companhia relativamente aos estilos e ação da Inquisição, exigindo moderação e reforma dos 
seus estilos. Estas vozes críticas advieram não só do questionamento da identidade evangélica de um tribunal desta natureza, mas também da ligação dos Jesuítas aos setores cristãos-novos e à conexação dos interesses deste com os interesses estratégicos da Companhia e dos interessses do Reino de Portugal defendidos por esta, ou ainda resultaram do facto de terem surgido conflitos institucionais por questão de privilégios e de aspetos doutrinais considerados questionáveis no pensamento teológico de alguns destacados jesuítas ${ }^{57}$.

Em suma, a relação dos Jesuítas, cristãos-novos e Inquisição nos séculos XVI e XVII compreende-se na trama complexa de uma sociedade tutelada pela Reino de Portugal e pela Igreja Católica, em que participavam uma diversidade de ordens religiosas em cooperação e concorrência, onde a Inquisição surge com o corpo distinto e centralizado na dependência do poder temporal do Rei e religioso do Papa que era preciso considerar na equação dos interesses mútiplos legitimados por um ideário que se queria unívoco.

Recebido: 19 de março de 2016 Aprovado: 22 de maio de 2016 Contato: joseeduardofranco@gmail.com

\footnotetext{
57 Ver a análise de Herman Prins Salomon, Queimar Vieira em Estáttua (Lisboa: Cátedra de Estudos Sefarditas 'Alberto Benveniste' e Rede de Judiarias de Portugal, 2015)
} 